\title{
BACK TO BASICS: GIANT CHALLENGES TO ADDRESSING ISAAC'S “GERIATRIC GIANTS" POST COVID-19 CRISIS
}

\author{
T.Ó. FLATHARTA ${ }^{1}$, E.C. MULKERRIN ${ }^{1}$ \\ 1. Department of Geriatric Medicine, University Hospital Galway, Galway, Ireland. Corresponding author: Dr. Tomás Ó Flatharta, Department of Geriatric Medicine, University Hospital \\ Galway, Galway, Ireland, t.oflatharta3@gmail.com
}

\begin{abstract}
The COVID-19 pandemic, being the greatest challenge to our healthcare system for over a century, has its greatest impact on older patients. This subgroup has higher morbidity and mortality than younger age groups. Superimposed on this, the major preventative intervention resulting in social isolation has negative consequences. Prof. Bernard Isaacs described the "Geriatric Giant Symptoms" in 1965 and encouraged the development of interventions for immobility, instability, incontinence and impaired intellect/memory with careful management of these symptoms resulting in better outcomes for older patients including reduced admissions to Nursing Homes and mortality. The author's explore the impact of the current pandemic and, most particularly its aftermath on the provision of such interventions. In the context of a major economic crisis, resources for highly effective interventions such as joint replacement surgery, urological interventions, cataract surgery will be all be limited after this crisis. Moreover delayed access to day patient services with suboptimal access to assessments for conditions such as cognitive decline and falls as well as social care will likewise militate against addressing the "Geriatric Giant Symptoms". Thus the "Founding Fathers" of Geriatric Medicine including Prof Isaacs would be justifiably concerned regarding our ability to deliver interventions to address the "Geriatric Giant Symptoms". Current leaders in geriatric medicine, healthcare workers, funders and providers as well as advocacy groups must redouble their efforts to ensure gains made in management of older patients over 2 generations are not lost in the aftermath of this pandemic.
\end{abstract}

Key words: Geriatric, elderly, COVID-19, pandemic, crisis.

\section{Introduction}

The COVID-19 pandemic has proven the greatest challenge to healthcare systems and society for over a century (1). Many strides in terms of infection control, medical diagnostics, disease management and epidemiology have occurred since then. The older population are proving more vulnerable to this current disease, with the median age of deaths being 82 years (2) compared to the median age of cases being 48 years(3) in Ireland as per figures from the Health Protection Surveillance Centre. This is thought to, at least partly, relate to the high prevalence of comorbidities such as hypertension and diabetes in that population (4). Thus, despite major advances, drastic alterations to our health system have been imposed with strict social distancing measures associated with "cocooning" of those older than 70 years. Social isolation and loneliness can lead to worsening of mental and physical health in older people (5). Since secondary care resources are focussed on targeting the infection and its consequences, non-urgent medical interventions have been deferred until further notice. In this article the potential impact of the above changes on older people during, but most importantly in the post COVID-19 pandemic period, will be explored.

\section{Threat to interventions for Isaac's "Giants Symptoms"}

When Bernard Isaacs, Professor of Geriatric Medicine at University of Birmingham, U.K., coined the phrase "Geriatric Giant Symptoms" referring to immobility, instability, Received May 4, 2020

Accepted for publication May 20, 2020 incontinence and impaired intellect/memory in 1965, he indicated that these are final common symptom pathways for many of the conditions of older patients which result in significant disability and utilisation of medical and social care services (6). He highlighted that these symptoms, when not addressed, often lead to poorer outcomes including transfer from the home environment to nursing homes as well as increased mortality. Due to a major transfer of resources to acute management of the coronavirus, many of the interventions which address these "Giant Symptoms" will be less accessible to older patients. Table 1 summarises interventions which will be under threat in the post COVID-19 era.

\section{Postponed elective surgical procedures}

To avoid potential virus exposure of people to high risk hospital campuses, and to create space for sufferers of the pandemic, many elective procedures have been postponed during this outbreak. Several procedures can have positive impacts on outcomes for older people. For example; for patients requiring joint replacement surgery such as total hip or total knee replacement, access to such surgery results in better outcomes in terms of improved pain control and improved mobility (7). It has also been shown that worse pre-operative health status, often a feature of delayed procedures, correlates with worse outcomes (8).

Cataract surgery has been shown to improve visual acuity and quality of life, even in those aged 85 years or older (9). Advanced cataract disease results in increased risk of falls, Published online June 22, 2020, http://dx.doi.org/10.1007/s12603-020-1425-1 
GIANT CHALLENGES TO ADDRESSING ISAAC'S “GERIATRIC GIANTS” POST COVID-19 CRISIS

Table 1

Challenges/Interventions which address "Giant symptoms" under threat during/post COVID-19 pandemic

\begin{tabular}{|c|c|c|c|}
\hline Challenge/Intervention & Setting & Giant Symptoms & Reference \\
\hline COVID-19 pandemic & $\begin{array}{l}\text { Inpatient } \\
\text { Community } \\
\text { Social Care }\end{array}$ & $\begin{array}{l}\text { Immobility } \\
\text { Instability } \\
\text { Incontinence } \\
\text { Impaired Memory }\end{array}$ & $(2)(3)(4)(5)(12)$ \\
\hline Elective joint replacement surgery & $\begin{array}{l}\text { Inpatient } \\
\text { Community }\end{array}$ & $\begin{array}{l}\text { Immobility } \\
\text { Instability }\end{array}$ & (7) $(8)$ \\
\hline Elective cataract surgery & $\begin{array}{l}\text { Inpatient } \\
\text { Community }\end{array}$ & $\begin{array}{l}\text { Instability } \\
\text { Immobility } \\
\text { Impaired memory }\end{array}$ & (9) \\
\hline Elective urological procedures & $\begin{array}{l}\text { Inpatient } \\
\text { Community }\end{array}$ & $\begin{array}{l}\text { Immobility } \\
\text { Incontinence } \\
\text { Impaired Memory }\end{array}$ & (10) (11) \\
\hline $\begin{array}{l}\text { Day/outpatient assessments } \\
\text { Cognitive assessments }\end{array}$ & $\begin{array}{l}\text { Inpatient } \\
\text { Community }\end{array}$ & $\begin{array}{l}\text { Immobility } \\
\text { Instability } \\
\text { Incontinence } \\
\text { Impaired Memory }\end{array}$ & (14) \\
\hline Falls assessment services & $\begin{array}{l}\text { Inpatient } \\
\text { Community }\end{array}$ & $\begin{array}{l}\text { Immobility } \\
\text { Instability } \\
\text { Incontinence } \\
\text { Impaired Memory }\end{array}$ & $(15)$ \\
\hline Social Care/Domiciliary supports & Community & $\begin{array}{l}\text { Immobility } \\
\text { Instability } \\
\text { Incontinence } \\
\text { Impaired Memory }\end{array}$ & (16) \\
\hline
\end{tabular}

acute and acute-on-chronic cognitive problems and an inability to read or access modalities such as watching television, computer use etc.

For older men, transurethral resection of the prostate (TURP) is comparable to conservative treatment with less complications (10). It is also effective in relieving lower urinary tract symptoms and leads to satisfactory patient-centred outcomes (11). Similarly, early access to investigative modalities such as cystoscopy and urodynamics studies help in early stratification of patients with urological problems, resulting in early appropriate medical management and/or referral for appropriate surgery.

As a result of the deferral of all but urgent procedures, major delays in provisions of orthopaedic, cataract and urological interventions due to increased waiting lists will be inevitable during and post the COVID-19 pandemic. This will undoubtedly result in increased pain levels, reduced mobility, increased incontinence, instability, cognitive symptoms and loss of independence as well as increased requirements for long term nursing care. This may be further compounded by a forecasted economic recession following this crisis (12) which will likely impact both the resources of the health service and the income of older people. This, in turn, will likely result in longer waiting times and increased risk of morbidity and mortality.

\section{Delayed outpatient/day patient medical services}

Many medical services are being affected, with inpatient length of stays of patients being minimised, and face to face outpatient/day patient assessment being replaced by virtual outpatient assessments in most cases. Delays in appropriate but non-urgent inpatient assessments and suboptimal outpatient assessment are likely. Despite virtual clinics having been previously demonstrated as equivalent to face to face assessments in some settings (13), this represents a new experience and difficult transition for both physicians and patients . Indeed remote assessment is less helpful for older patients with complex comorbidities, nuanced presentations, cognitive difficulties etc.

Moreover early access to assessment and diagnostic evaluation, including scans, for patients with acute or acute-onchronic cognitive decline results in better outcomes for patients (14). Again, because many of these services have been severely curtailed and defined as non-urgent during the COVID-19 crisis, a major backlog will likely develop. The provision and expansion of such services, which are already restricted in many jurisdictions, may not be possible due to the economic meltdown following the COVID-19 crisis. Likewise, early assessment of older patients at risk of falls is associated with improved mobility, reduced falls and associated injuries (long bone fracture, head and soft tissue injuries) as well as increased independence for older people (15). Access to existing services 


\section{THE JOURNAL OF NUTRITION, HEALTH \& AGING}

could be restricted due to significant backlogs as a result of this crisis, and planned expansion of such services could be impaired due to lack of resources.

\section{Decreased social supports}

Superimposed on the aforementioned social isolation and "cocooning" leading to social anxiety, domiciliary supports are also suffering. Social care in the community provides essential support and reduces pressure on secondary care facilities while maintaining patients with some independence in their own homes (16). It is also a vital support for carers who are frail and struggling to care for their older relatives. Like many other resources, social care funding prior to the COVID19 pandemic were suboptimal and limited, with access to domiciliary physiotherapy, psychological support services, occupational therapy and day care facilitates rationed. Given the massive diversion of resources to the acute sector compounded by the bleak economic outlook, such supports may likewise be restricted even more after the pandemic.

\section{Discussion}

In summary, a likely limitation of vital interventions to address and prevent Isaac's Geriatric Giant symptoms of older patients could present an unprecedented challenge when the current pandemic is resolved. Moreover, timely access to screening investigations such as bowel and breast cancer screening will likely be more difficult. The "Founding Fathers" including Prof Isaacs and contemporaries like Prof John Pathy, Cardiff University, with whom a co-author (EM) had the honour of working, and Prof John Brocklehurst of University of Manchester were renowned for their vision, political nous and relentless tenacity.

Current clinical leaders including Consultant Geriatricians, aided by allied health professionals, older patient advocacy groups and people of all ages must be prepared for similar relentless advocacy to maintain and expand services for older people. This should be focussed on ensuring that the most vulnerable older people, who arguably suffered most in terms of morbidity, mortality and isolation restrictions, receive maximum support and access to appropriate services in what will be a volatile socioeconomic environment following this pandemic. Criticism of the lack of preparedness of Governments, society and services for the pandemic has been widespread. The preparedness of our speciality and healthcare providers/funders to meet the challenges ahead, will dictate how well we can minimise the negative impact on our older patients. Giant efforts are required aimed at avoiding the relinquishment of massive ground gained over 2 generations in developing older person's services.

\section{Key Points}

- The COVID-19 pandemic predominantly leads to morbidity and mortality in older patients and the response including preventative measures adversely affect older patients

- The virtual abandonment of non-urgent interventions during the crisis combined with an economic meltdown could lead to major delays in accessing and expanding interventions and services to address the "Geriatric Giant Symptoms"

- Delays in joint replacement and cataract surgery, urological surgery and interventions, day patient, falls and cognitive assessments as well as depleted social care funding will likely worsen after this pandemic

- Giant efforts by clinician leaders, healthcare providers and funders, advocacy groups and the population in general is required to minimise the negative impact on older patient services post the COVID-19 pandemic.

Conflict of interest: None.

Ethical standard: Not applicable.

\section{References}

1. Viboud C, Lessler J. The 1918 Influenza Pandemic: Looking Back, Looking Forward. Am J Epidemiol. 2018 Dec 1;187(12):2493-7.

2. Ireland DoH. Statement from the National Public Health Emergency Team - Monday 13 April. Department of Health Ireland; 2020: 1. Available online: https://www.gov.ie/ en/press-release/466968-statement-from-the-national-public-health-emergency-teammonday-13-a/

3. Centre HPS. Epidemiology of COVID-19 in Ireland. 2020 20/04/2020. Report No. Available online: https://www.hpsc.ie/a-z/respiratory/coronavirus/novelcoronavirus/ casesinireland/epidemiologyofcovid-19inireland/

4. Garnier-Crussard A, Forestier E, Gilbert T, Krolak-Salmon P. Novel Coronavirus (COVID-19) Epidemic: What Are the Risks for Older Patients? J Am Geriatr Soc 2020. Available online: https://doi.org/10.1111/jgs.16407

5. Courtin E, Knapp M. Social isolation, loneliness and health in old age: a scoping review. Health Soc Care Community. 2017 May;25(3):799-812.

6. Isaacs B. An Introduction to Geriatrics: London : Baillière : Tindall \& Cassell; 1965

7. Ethgen O, Bruyere O, Richy F, Dardennes C, Reginster JY. Health-related quality of life in total hip and total knee arthroplasty. A qualitative and systematic review of the literature. J Bone Joint Surg Am. 2004 May;86(5):963-74.

8. Jamsen E, Puolakka T, Eskelinen A, Jantti P, Kalliovalkama J, Nieminen J, et al Predictors of mortality following primary hip and knee replacement in the aged. A single-center analysis of 1,998 primary hip and knee replacements for primary osteoarthritis. Acta Orthop. 2013;84(1):44-53

9. Li E, Margo CE, Greenberg PB. Cataract surgery outcomes in the very elderly. Journa of Cataract \& Refractive Surgery. 2018;44(9):1144-9.

10. Lin YH, Hou CP, Chen TH, Juang HH, Chang PL, Yang PS, et al. Transurethra resection of the prostate provides more favorable clinical outcomes compared with conservative medical treatment in patients with urinary retention caused by benign prostatic obstruction. BMC Geriatr. $2018 ; 18(1): 15$.

11. Brierly R, Mostafid A, Kontothanassis D, Thomas P, Fletcher M, Harrison N. Is transurethral resection of the prostate safe and effective in the over 80-year-old? Annals of the Royal College of Surgeons of England. 2001;83:3.

12. Fernandes N. Economic Effects of Coronavirus Outbreak [COVID-19] on the World Economy. Social Science Research Network: SSRN, 2020 22/03/2020. Report No. Available online: https://dx.doi.org/10.2139/ssrn.3557504

13. Long R, Heffernan C, Gao Z, Egedahl M, Talbot J. Do "Virtual" and "Outpatient" Public Health Tuberculosis Clinics Perform Equally Well? A Program-Wide Evaluation in Alberta, Canada. PLoS ONE.2015;10(12). Available online: https://doi org/10.1371/journal.pone.0144784

14. Koch T, Iliffe S, project E-E. Rapid appraisal of barriers to the diagnosis an management of patients with dementia in primary care: a systematic review. BMC Fam Pract. 2010;11:52.

15. Hill K, Schwarz J. Assessment and management of falls in older people. Internal Medicine Journal. 2004;34(9-10):557-64

16. Tomaka J, Thompson S, Palacios R. The Relation of Social Isolation, Loneliness, and Social Support to Disease Outcomes Among the Elderly. Journal of Aging and Health 2006;18(3):359-84. 